\title{
THE EFFECT OF PLGA-COLLAGEN I PATCH ON INGUINAL HERNIA
}

\author{
FANGJIE ZHANG, GUODONG GAO *, PING WANG, JING YE, YONGGANG HUANG, HAO WU
}

Department of Hernia and Abdominal Wall Surgery, Hangzhou First People's Hospital, Hangzhou, 310006, China

*corresponding author: gaoguodonghzfph@163.com

Manuscript received: January 2018

\begin{abstract}
Different approaches are used for the treatment of inguinal hernia, and patches play a central role. This study aimed to investigate the efficacy of a new patch with poly(lactic-co-glycolic acid) (PLGA) - Collagen I, on a murine model of inguinal hernia. 30 rats with induced abdominal wall defect were divided into 2 groups, an experimental group and a control group, 15 animals per group. The experimental group was treated with PLGA-Collagen I patch implanted with bone marrow mesenchymal stem cells (BMSCs) and the control group was treated with cell-free PLGA-Collagen I patch. After implantation each group was divided in 3 subgroups, 5 animals per subgroup intended to evaluate the changes at 1, 2 and 6 months. The proinflammatory factors IL-6 (interleukin -6) and IL-10 (interleukin -10) were investigated at 7, 14 and 28 days after implantation. The peritoneal inflammatory reactions were evaluated by identifying the macrophage surface antigen modifications in tissue. The regeneration of the tissue in the patch and the degradation state of the material was evaluated by haematoxylin-eosin (HE) staining. SEM was used to observe the integrity of peritoneum and the angiogenesis was detected by immunohistochemistry. After a week, the macrophages of both groups were significantly increased; after one month, the inflammatory reaction gradually subsided and the number of macrophages decreased. One month after surgery, there was no swelling in the abdominal wall of the experimental group and the control group. The PLGA-Collagen I patch of BMSCs can promote cell infiltration, angiogenesis and tissue regeneration. The degradation rate of PLGA increased. In sixth months, the BMSCs PLGA-Collagen I was almost completely degraded compared with cell free PLGA-Collagen I patches, in which the degradation was slower. PLGA-Collagen I tissue engineering materials planted with BMSCs can promote the repair of abdominal injury and can be a good candidate for the treatment of abdominal wall defects.
\end{abstract}

\section{Rezumat}

În abordarea terapeutică a herniei inghinale plasturii joacă un rol central. Acest studiu a urmărit investigarea eficacității unui plasture nou, conținând o asociere a colagenului de tip I cu poli(acid lactic-co-glicolic) (PLGA), pe un model murin de hernie inghinală. 30 de şobolani cu defect de perete abdominal indus au fost împărțiți în două grupuri, un grup experimental şi un grup de control, 15 animale/grup. Grupul experimental a fost tratat cu plasturi PLGA-colagen I implantat cu celule stem mezenchimale (BMSC) din măduva osoasă, iar grupul martor a fost tratat cu plasturi PLGA-colagen I fară celule. După implantare, fiecare grup a fost împărțit în 3 subgrupuri, 5 animale/subgrup, destinate evaluării modificărilor după 1,2 şi 6 luni. Au fost determinaţi factorii proinflamatori IL-6 (interleukina -6) şi IL-10 (interleukina -10) la 7, 14 şi 28 de zile după implantare. Reacțiile inflamatorii peritoneale au fost evaluate prin identificarea modificărilor antigenului de suprafață a macrofagelor. Regenerarea țesutului și starea de degradare a materialului a fost evaluată prin colorație hematoxilină-eozină (HE). Microscopia electronică a fost utilizată pentru a observa integritatea peritoneului, iar angiogeneza a fost detectată prin imunohistochimie. Testele pe termen lung au arătat că plasturele ar putea promova sinteza fibrelor de colagen, regenerarea vaselor de sânge și repararea leziunii peretelui abdominal.

Keywords: PLGA-Collagen I patch; inguinal hernia; macrophage; inflammatory response, IL-6, IL-10

\section{Introduction}

Inguinal hernia is a protrusion of the abdominal canal through the abdominal contents of the abdominal wall defect, known as direct hernia and oblique hernia [1, 2]. Direct hernia occurs mainly in adults. Compared with the oblique hernia, it is more likely to recur [3]. Most hernia do not have high risk, and can be operated to repair the defect. If hernia seriously affects the supply of blood flow in the intestines, surgical intervention is needed [4-6]. Currently, more and more studies show that the formation of abdominal hernia does not come from abdominal wall wear [7-9], but it is a group of histological lesions caused by disturbed collagen metabolism and systemic connective tissue damage [10]. The disease has a certain degree of correlation with the heredity and acquired factors. Therefore, the incidence of hernia is not formed independently. It is a systemic disease caused by a variety of factors. Hernia repair is a common general surgery. The aim is to reduce the patient's pain and complications, to repair the defect and the weak point. Inguinal hernia has many treatments and approaches, such as open surgical suture, open patch repair, laparoscopic patch repair, etc. $[12,13]$. There are various patch materials available on the pharmaceutical market, some of them being expensive [17]. This study aimed to investigate 
FARMACIA, 2018, Vol. 66, 5

the repair effect of a new patch material, poly(lacticco-glycolic acid) (PLGA) - Collagen I patch on inguinal hernia.

\section{Materials and Methods}

\section{Reagents}

Foetal bovine serum (Shenzhen Kangchuyuan Co., Ltd., Shenzhen, China); immunohistochemistry kits (Thermo Fisher Scientific (China) Co., Ltd., Shanghai, China); EDTA (ethylenediaminetetraacetic acid) (China bioengineering Biotechnology (Shanghai) Co., Ltd., Shanghai, China); DAB (diaminobenzidine) colour box (Beijing Baiaolaibo Technology Co., Ltd., Beijing, China); PLGA75/25 (Sigma, USA); HFIP (hexafluoroisopropanol) (Sigma,USA); collagen I (Sigma, USA); chloroform, acetone, phosphate buffer solution (PBS) and heparin sodium (Wuhan Biocar Biological Medicine Co., Ltd., Wuhan, China); tween-20 (Hubei Xinxin Jiali Biotechnology Co., Ltd., Wuhan, China); normal saline (Foshan City Comfort Medical and Health Supplies Co., Ltd., Foshan, Guangdong); polyoxymethylene (POM) (Shandong West Asia Chemical Industry Co., Ltd., Linyi, Shangdong); vWF antibody and F4/80 antibody (Abcam, USA); CCR7 (CC receptor 7) antibody, CD206 antibody, BSA(bovine serum albumin), 3,3'-diaminobenzidine (DAB) chromogenic solution and Masson 's stain (Wuhan BOSTER Biological Technology Co. Ltd, Wuhan, China); PKH26 Kit (Red Fluorescent Cell Linker Kit; Sigma, USA); IL-6 and IL-10 ELISA Kits (Shanghai Meilian Biotechnology Co., Ltd., Shanghai, China); DMSO (dimethylsulfoxide) (Changzhou City Chemical Co., Ltd., Changzhou, China).

\section{Equipment}

Ultra-quiet workbench (Shanghai Qiao Yue Electronics Co., Ltd., Shanghai, China); carbon dioxide cell culture box (Shandong Boke Biological Industry Co., Ltd., Jinan, China); digital electron microscope (DEM) inverted fluorescence microscope (Shunyu Optical Technology Co., Ltd., Ningbo, China); pH-meter and scanning electron microscope (Nantong Water Environmental Protection Technology Co., Ltd., China); high-voltage electrostatic spinning machine (Tianjin Yunfan Tech. Co., Ltd., Tianjin,China); electronic balance (Shanghai Jingpie Instrument Co., Ltd., Shanghai, China); Telstar freeze dryer (Telstar, Spain); paraffin embedding machine and paraffin slicer (Leica, Germany); automatic microplate reader (Thermo, USA); scanning electron microscopy (Olympus, Japan); laser scanning confocal microscope (Leica, Germany).

Preparation of PLGA collagen scaffolds

The PLGA was dissolved in HFIP (hexafluoroisopropanol) at a concentration of $20 \%$. Collagen I was also dissolved in HFIP at a concentration of $6.66 \%$. The ratio of PLGA: Collagen I was 1:1 (v/v). The mixture was loaded into the spinning tube (diameter 21). The PLGA-Collagen I scaffold was prepared by electrostatic spinning using a roller rotating at a uniform speed using a voltage of $18 \mathrm{kV}$, a distance of $153 \mathrm{~cm}$ and a flow velocity of the spinning solution of $1 \mathrm{~mL} / \mathrm{h}$. Then the PLGA-Collagen I scaffold was freezedried for $24 \mathrm{~h}$.

Extraction and identification of seed cells

Six healthy, four weeks old Sprague Dawley male rats with an average weight of $110 \mathrm{~g}$ were selected. The rats were acclimatized to the new laboratory conditions for one week: constant temperature of $24 \pm 1{ }^{\circ} \mathrm{C}$, relative humidity of $50 \pm 5 \%$ and $12 \mathrm{~h}$ light - dark with free access to feed and water. The rat bone marrow mesenchymal stem cells were extracted from the bone marrow of the rats and identified by MTT (3-[4,5-dimethylthiazol-2-yl]-2,5 diphenyl tetrazolium bromide) assay and immunohistochemistry. The animal study was approved by the Ethics Committee of the Hangzhou First People's Hospital, Hangzhou and the animal handling methods involved in the experiment were also in line with the International Animal Health Regulations.

Isolation and culture of rat bone marrow mesenchymal stem cells. Rats were sacrificed using pentobarbital (Shanghai Xinya Pharmaceutical Co., Ltd, 40 mg/kg bw) injected intraperitoneally. Afterwards, the body was immersed in $90 \%$ benzalkonium bromide solution for 2 minutes and then disinfected with $75 \%$ alcohol for 3 - 5 minutes. The skin of hind limbs was cut and tibia and femur were removed for extracting the bone marrow from the cavity. After extraction of the bone marrow it was cleaned with $2 \mathrm{~mL}$ PBS until the bone became white. After washing all the bones, the cells were dispersed in the liquid by gentle blow repeatedly with a $1 \mathrm{~mL}$ transporter. Then the cell suspension was transferred into a $15 \mathrm{~mL}$ centrifugal tube with 200 mesh nylon grid filters placed at the orifice of the tube. The filtrate of the centrifugal tube was collected and centrifuged at $1000 \mathrm{rpm}$ for 6 minutes. When the supernatant was discarded, the cells were read. The cells were mixed with $2-3 \mathrm{~mL}$ erythrocyte lysate and kept for 2 minutes at room temperature. After lysis, the same volume of FBS was added to stop the lysis and centrifuged at $1000 \mathrm{rpm}$ for 6 minutes. The cells were cultured in $\mathrm{CO}_{2}$ with $9 \mathrm{~mL}$ for $1 \mathrm{~mL}$ of cell suspension. After 24 hours of culture, half of liquid was changed and again changed after the third day. Cells were sub-cultured when the bottom of the dish was about $80 \%$. Medium was absorbed and $800 \mu \mathrm{L} 0.25 \%$ digestive juice containing EDTA was added. The trypsin was slightly shaken to cover the whole dish. Microscopically, the cells contracted and became round. When most of the cells contracted and there was a moderate amount of floating liquid, the digestion was terminated by adding a complete medium. MTT assay [11]

The enlarged third-generation bone marrow mesenchymal stem cells were mixed with $10 \%$ foetal bovine serum full medium and inoculated into 96-well plate. The 
FARMACIA, 2018, Vol. 66, 5

cells were cultured in a constant temperature incubator with $5 \% \mathrm{CO}_{2}$ at $37^{\circ} \mathrm{C}$ for nine days. On the fourth day, the complete culture medium was replaced according to the conventional method to avoid cell death due to insufficient nutrition and increased metabolic waste. Starting from the first day after inoculation, one plate was taken daily for testing. $20 \mu \mathrm{L}$ MTT solution was added to each plate hole and incubated for 4 hours in a constant temperature incubator at $37^{\circ} \mathrm{C}$ and $5 \% \mathrm{CO}_{2}$. Subsequently, the liquid in the hole was carefully sucked out with a pipette, and then $150 \mu \mathrm{L}$ DMSO was added and let to react for 10 minutes on the oscillator to dissolve the crystals. The absorbance values (OD values) of each hole were measured with an automatic enzyme labelling instrument, $\lambda=492 \mathrm{~nm}$. Immunohistochemical identification of the cells The immunohistochemical identification of the cells standard haematoxylin stained was used and the expression of CD34, CD44, CD45 and CD105 was established.

The animal model

In this study, an animal model of abdominal wall defect was used to investigate the effect of PLGACollagen I Patch on the repair of abdominal wall defects. 30 healthy, four weeks old CD-SD male rats were selected. Ketamine (Qigihar Second Pharmaceutical Co., Ltd., China) in doses of $100 \mathrm{mg} / \mathrm{kg}$ bw intraperitoneal was used to anesthetize the rats. The lower abdomen of the rat was sterilized with $70 \%$ alcohol. Then, the abdominal wall fascia and abdominal muscle, internal oblique was reserved and next to the spermatic cord a defect of abdominal wall was made. After the model was obtained, the rats were divided into two groups: the experimental group (15 rats) and the control group (15 rats). The experimental group: BMSCs (bone marrow mesenchymal stem cells) labelled with PKH26 (Red Fluorescent Cell Linker Kit) was planted on the PLGA-Collagen I collagen scaffold. The planted of the cells on the scaffold was made as follows: $500 \mu \mathrm{L} 2 \times 10^{6}$ cell suspension was cultured for $2 \mathrm{~h}$ at 37 and $5 \% \mathrm{CO}_{2}$ with the scaffold. After complete adsorption, the complete culture medium was added to up to $5 \mathrm{~mL}$ to continue the culture for $22 \mathrm{~h}$. the control group: the same size PLGA-Collagen I collagen scaffold was placed directly in the complete medium for soaking $24 \mathrm{~h}$.

A

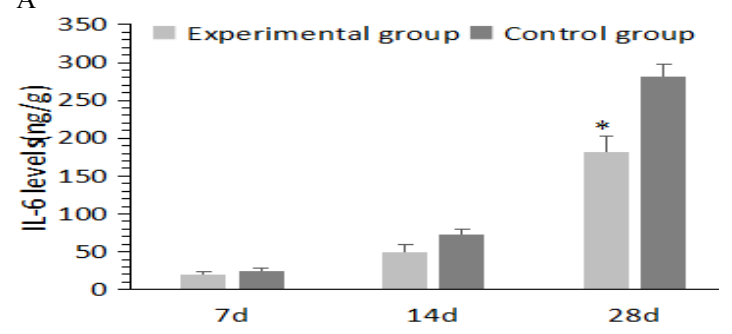

Figure 1.

IL-6 and IL-10 levels in the two groups at 7, 14 and 28 days after treatment $(* \mathrm{p}<0.05, * * \mathrm{p}<0.001$, experimental $v s$ control group)
The processed materials were transplanted into the inguinal hernia model, and the animals were subdivided into 3 respectively groups ( 5 animals per group) and observed for 1,2 and respectively 6 months. The abdominal wall of the experimental group and the control group were slightly swollen after operation. However, this does not affect the activity.

We evaluate the plasma pro-inflammatory factors IL-6 and IL-10 using ELISA kits according to manufacturer instructions. Immunohistochemistry was used to detect macrophage surface antigen F4/80, CCR7 and CD206. The number of cells in macrophages, M1 macrophages and M2 macrophages were assessed to analyse the inflammatory reaction. HE staining was used to observe the regeneration of the tissue and the degradation state of the patch.

At each observation point (1,2 and 6 months) 5 animals from each group were sacrificed using pentobarbital injected intraperitoneally in doses of $40 \mathrm{mg} / \mathrm{kg}$ bw. The peritoneal tissues were collected and stained with HE (haematoxylin-eosin). SEM (scanning electron microscope) was used to observe the integrity of peritoneum, the angiogenesis state was detected by immunohistochemistry and the formation of collagen fibber was detected by Masson's trichrome staining. Statistical analysis

The data obtained in this study were statistically analysed with SPSS19.0 software. The analysis of variance and q test were used in each group. The paired Student's $t$ test was used among the groups. The difference was statistically significant at $\mathrm{p}<0.05$.

\section{Results and Discussion}

The expression of IL- 6 and $I L-10$

In the experimental group and the control group, IL-6 increased continuously in the first 28 days. In the experimental group, IL- 6 increased less than in the control group and the difference between the two groups was statistical significant at the $28^{\text {th }}$ day $(\mathrm{p}<0.05)$ (Figure 1A). IL-10 levels increased till the $14^{\text {th }}$ day and after started to decrease. In the experimental group IL-10 level was higher than that of the control group, and the difference was statistical significant in the $28^{\text {th }}$ day $(\mathrm{p}<0.001)$ (Figure $\left.1 \mathrm{~B}\right)$.

B

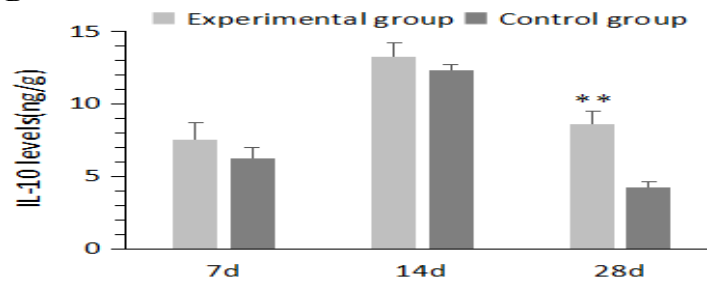


FARMACIA, 2018, Vol. 66, 5

Immunohistochemical detection of macrophages As shown in Figure 2, the distribution of macrophage infiltration stents in the experimental group was higher than that in the control group. The total macrophages in the two groups reached the maximum on the seventh day. However, on the fourteenth and the 28 day, they all decreased gradually (Figure 2A). The control group began to decrease when the M1 type macrophage reached the maximum at $14^{\text {th }}$ day, while the experimental group presented a descendent trend from the $7^{\text {th }}$ day (Figure $2 \mathrm{~B}$ ). In the $28^{\text {th }}$ day, the M2 cells in both the control group and the experimental group were gradually reduced, and the M2 cells in the experimental group increased compared to the control group (Figure 2C).
A

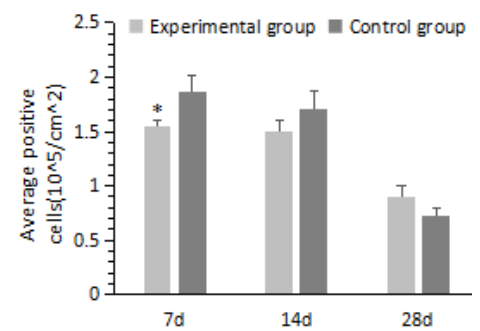

B

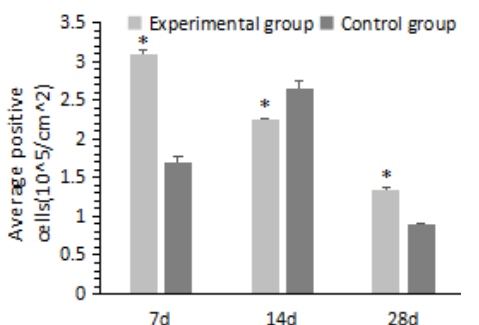

C

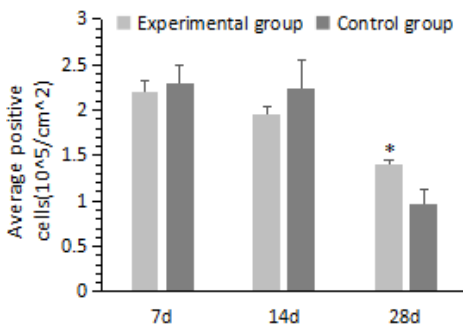

Figure 2.

Macrophage distribution in the 2 groups at 7, 14 and 28 days after treatment (A: anti-F4/80, B: anti-CCR7, $\mathrm{C}$ : anti-CD206; $* \mathrm{p}<0.05$, experimental vs control group)

The regeneration of the tissue in the patch and the degradation state of the patch by HE staining

The results of HE staining showed that the boundary of the patch material in the experimental group grew tightly together with the surrounding tissue of the animal, while the control group was not close to the experimental group. As shown in Figure 3, in both groups it could be seen a degradation of the material in the first and second months. In the sixth month, for the experimental group, the patch materials were almost completely degraded, while in the control group, there was still PLGA in the sixth month, and the degradation rate was low.

\section{The integrity of the peritoneum}

As shown in Figure 4, the peritoneal integrity of the experimental group was superior to that of the control group.



Figure 3.

The degradation state of materials by HE staining (A: experimental group, B: control group, the numbers denote the month) 


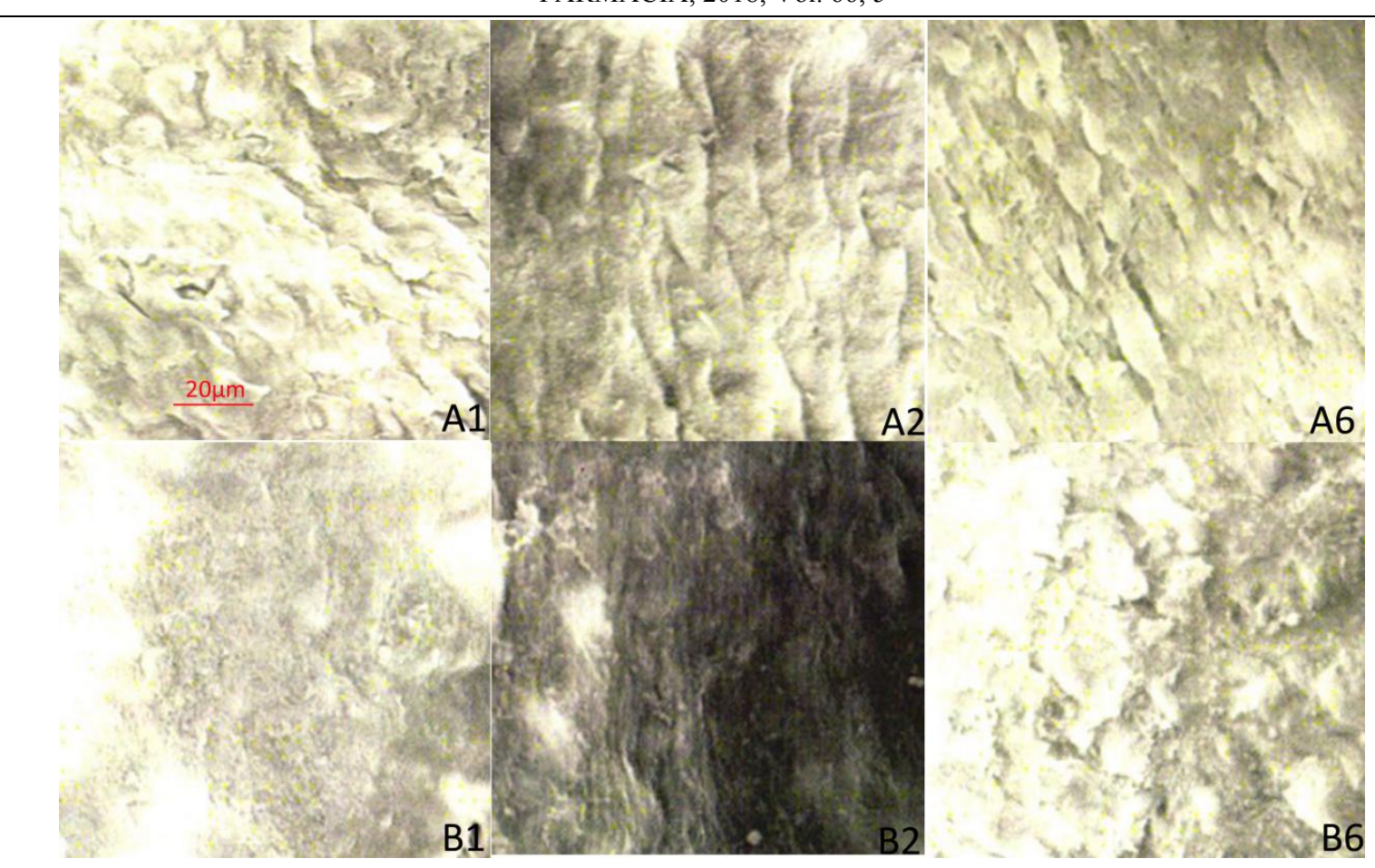

Figure 4.

The peritoneal integrity observed by scanning electron microscopy $(20 \mu \mathrm{m})(\mathrm{A}$ : experimental group, B: control group, the numbers denote the month)

Formation of blood vessels and collagen fibbers

As can be seen from Figure 5A and Figure 5B, the capillary density in the experimental group was significantly higher than the control group, and the number of mature blood vessels in the experimental group was significantly higher than that of the control group.

The number of collagen fibbers in the experimental group was increased compared with the control group (Figure 5C). Moreover, in the study, it was found that the collagen fibber dimension of the experimental group increased gradually over time, and was more regular and coherent. On the contrary, the collagenous fibbers in the control group were arranged in an irregular state. In the experimental group, the PLGACollagen I scaffold was degraded gradually and was replaced by new tissue and collagen fibbers. After six months, the PLGA-Collagen I scaffold was almost completely degraded and replaced by its own tissue. In the control group, the PLGA-Collagen I scaffold was degraded. It does not produce more new-born tissues and collagen fibbers. After six months, there was still no complete degradation of PLGA-Collagen I stents and no substitute for new tissue.
A

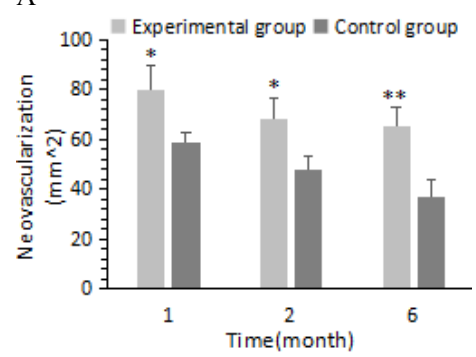

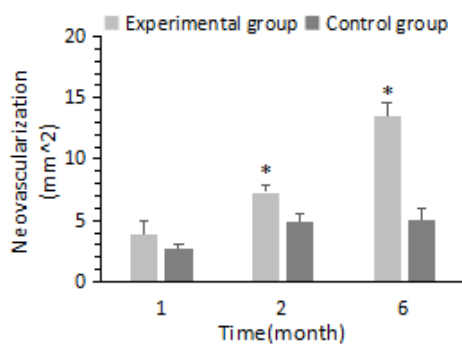

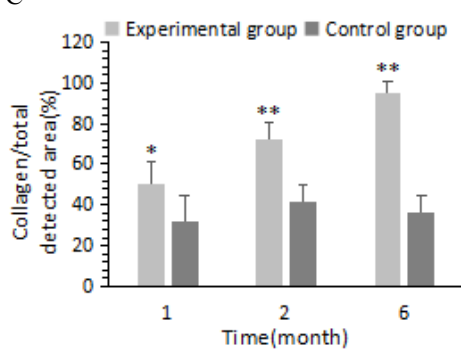

Figure 5.

Formation of blood vessels and collagen fibbers in the two groups after 1,2 and 6 months of treatment (A: capillary,

B: mature vessel, C: collagen fibbers formation; ${ }^{*} \mathrm{p}<0.05,{ }^{* *} \mathrm{p}<0.001$, experimental $v s$ control group)

Abdominal wall defects and treatment of abdominal hernia focus on to restoring the integrity of the abdominal wall. However, the pathophysiological and pathological factors make that the simple tissue suture repair, in order not to achieve long-term treatment
[14-16]. Therefore, combined with the anatomy of the inguinal region, the patch material may be used to repair the abdominal wall. It can provide the growth support for the patient's fibrous tissue [18]. Currently, most of the patch materials are not bio- 
FARMACIA, 2018, Vol. 66, 5

degradable and have a high price, which make them inappropriate for wide use. PLGA is a nontoxic, nonantigenic, safe and adjustable degradation rate polymer $[19,20]$. However, the adsorption capacity of cells is weak. It may cause the decrease of the local $\mathrm{pH}$ in the process of degradation, which leads to aseptic inflammation [21-23]. In this study, rat BMSC cells were used as model. The PLGA-Collagen I tissue engineering patch was synthesized by high voltage electrostatic spinning machine. It was found that the BMSCs and PLGA-Collagen I materials have good compatibility in vitro. Afterwards, an animal model of abdominal wall defect was established. After a week of implantation on the abdominal wall tissue of rats, the two groups of animals developed stimulate the inflammatory response in the local tissue. Macrophages were significantly increased, which is consistent with the body's response to foreign body. If the implants are not compatible with the body, there will be produced gradual and intense rejection reactions $[24,25]$. The number of inflammatory cells increased gradually. The part of the cell is necrotic and suppurative. Until the material was removed, the local and systemic inflammatory response was subsided [26]. In this study, after one month, the inflammatory response gradually subsided and the number of macrophages decreased. Moreover, the BMSCs patch can promote the synthesis of collagen fibbers, regeneration of blood vessels and repair of abdominal wall injury. After long-term experimental observation, the abdominal wall of the rats in the experimental group and the control group had no swelling, and the rats were healthy. At 1 month, 2 months and 6 months after operation, the morphological and SEM micrographs were observed. The PLGA-Collagen I patch with BMSCs can promote the fusion of the tissue and the material. It can promote cell infiltration, angiogenesis and tissue regeneration. The degradation rate of PLGA materials was faster. After sixth months, the cell based patch was almost completely degraded. However, PLGA-Collagen I patches on which there were no planted cells were degraded slower. The degradation in this case was done in pieces and remained in the body as a foreign material. The PLGA-Collagen I tissue engineering material with BMSCs is a biodegradable polymer material. After the operation, with the continuous growth of the abdominal wall tissue, it can accelerate the repair of the abdominal wall injury, so as to achieve the purpose of treating the abdominal wall defect. In this process, the material is eventually completely degraded and replaced by the new tissue.

\section{Conclusions}

This study shows the efficacy of PLGA-Collagen I patch with BMSCs in the treatment of abdominal hernia, by restoring the integrity of the abdominal wall. This can be a non-expensive and safe alternative for the treatment of inguinal hernia.

\section{References}

1. Langeveld HR, van't Riet M, Weidema WF, Stassen LP, Steyerberg EW, Lange J, Bonjer HJ, Jeekel J, Total extraperitoneal inguinal hernia repair compared with Lichtenstein (the LEVEL-Trial): a randomized controlled trial. Ann Surg., 2010; 251(251): 819-824.

2. Hansen TG, Pedersen JK, Henneberg SW, Pedersen DA, Murray JC, Morton NS, Christensen K. Academic performance in adolescence after inguinal hernia repair in infancy: a nationwide cohort study. Anesthesiology, 2011; 114(5): 1076-1085.

3. Hallén M, Bergenfelz A, Westerdahl J, Laparoscopic extraperitoneal inguinal hernia repair versus open mesh repair: long-term follow-up of a randomized controlled trial. Surgery, 2008; 143(3): 313-317.

4. Bittner R, Arregui ME, Bisgaard T, Dudai M, Ferzli GS, Fitzgibbons RJ, Fortelny RH, Klinge U, Kockerling F, Guidelines for laparoscopic (TAPP) and endoscopic (TEP) treatment of inguinal Hernia [International Endohernia Society (IEHS)]. Surg Endosc., 2012; 26(11):3350-3351.

5. Bittner R, Montgomery MA, Arregui E, Bansal V, Bingener J, Bisgaard T, Buhck H, Dudai M, Ferzli GS, Update of guidelines on laparoscopic (TAPP) and endoscopic (TEP) treatment of inguinal hernia (International Endohernia Society). Surg Endosc., 2015; 29(2): 289-321.

6. Alfieri S, Amid PK, Campanelli G, Izard G, Kehlet H, Wijsmuller AR, Di Miceli D, Doglietto GB, International guidelines for prevention and management of post-operative chronic pain following inguinal hernia surgery. Hernia, 2011; 15(3): 239-249.

7. Klinge U, Binnebösel M, Mertens PR, Are collagens the culprits in the development of incisional and inguinal hernia disease?. Hernia, 2006; 10(6): 472-477.

8. Read RC, Herniology: past, present, and future. Hernia, 2009; 13(6): 577-580.

9. Miserez M, Peeters E, Aufenacker T, Bouillot JL, Campanelli G, Conze J, Fortelny R, Heikkinen T, Erratum to: Update with level 1 studies of the European Hernia Society guidelines on the treatment of inguinal hernia in adult patients. Hernia, 2009; 13(4): 343-403.

10. Simons M P, Aufenacker T, Bay-Nielsen M, Miserez M, Update with level 1 studies of the European Hernia Society guidelines on the treatment of inguinal hernia in adult patients. Hernia, 2009; 13(4): 343-403.

11. Pîrvu L, Sha'at F, Miclea LC, Savopol T, Neagu G, Udeanu DI, Moisescu MG, Polygonum bistorta L. herba et flores. Polyphenols profile, antioxidant properties and cytotoxic effect on murine fibroblast cell line NIH3T3. Farmacia, 2017; 65(4): 571-576.

12. Pokorny H, Klingler A, Schmid T, Fortelny R, Hollinsky C, Kawji R, Steiner E, Pernthaler H, open inguinal hernia repair: results of a prospective randomized multicenter trial. Hernia, 2008; 12(4): 385-389.

13. Evans MD, Williams GL, Stephenson BM, Low recurrence rate after laparoscopic (TEP) and open (Lichtenstein) inguinal hernia repair: a randomized, multicenter trial with 5-year follow-up. Ann Surg., 2009; 249(1): 33-38. 
14. Dulucq JL, Wintringer P, Mahajna A, Laparoscopic totally extraperitoneal inguinal hernia repair: lessons learned from 3,100 hernia repairs over 15 years. Surg Endosc., 2009; 23(7): 1687-1688.

15. Krishna A, Misra MC, Bansal VK, Kumar S, Rajeshwari S, Chabra A, Laparoscopic inguinal hernia repair: transabdominal preperitoneal (TAPP) versus totally extraperitoneal (TEP) approach: a prospective randomized controlled trial. Surg Endosc., 2012; 26(3): 639-649.

16. Bökkerink WJ, van Laarhoven CJ, Koning GG, Comment to: Update with level 1 Studies of the European Hernia Society guidelines on the treatment of inguinal hernia in adult patients, Hernia, 2014; 18(5) :771-772.

17. Castañeda PS, Escobar-Chávez JJ, Aguado AT, Rodríguez Cruz IM, Melgoza Contreras LM, Design and evaluation of a transdermal patch with atorvastatin. Farmacia, 2017; 65(6): 908-916.

18. EU Hernia Trialists Collaboration, Laparoscopic compared with open methods of groin hernia repair in adults: a systematic review of clinical controlled trials. $\mathrm{Br} J$ Surg., 2010; 87(7): 860-867.

19. Wang $\mathrm{CH}$, Wang S, Zhang B, Zhang XY, Tong XJ, Peng HM, Han XZ, Liu C, Layering Poly (lactic-coglycolic acid)-based electrospun membranes and coculture cell sheets for engineering temporomandibular joint disc. J Biol Regul Homeost Agents, 2018; 32(1): $55-61$.

20. Luu YK, Kim K, Hsiao BS, Chu B, Hadjiargyrou $\mathrm{M}$, Development of a nanostructured DNA delivery scaffold via electrospinning of PLGA and PLA-PEG block copolymers. J Control Release., 2003; 89(2): 341-353.

21. Owen GR, Jackson J, Chehroudi B, Burt H, Brunette DM, A PLGA membrane controlling cell behaviour for promoting tissue regeneration. Biomaterials, 2005; 26(35): 7447-7456.

22. Baker SC, Rohman G, Southgate J, Cameron NR, The relationship between the mechanical properties and cell behaviour on PLGA and PCL scaffolds for bladder tissue engineering. Biomaterials, 2009; 30(7): 13211328.

23. Koegler WS, Griffith LG, Osteoblast response to PLGA tissue engineering scaffolds with PEO modified surface chemistries and demonstration of patterned cell response. Biomaterials, 2004; 25(14): 2819-2830.

24. Bringman S, Wollert S, Osterberg J, Smedberg S, Granlund H, Heikkinen TJ, Three-year results of a randomized clinical trial of lightweight or standard polypropylene mesh in Lichtenstein repair of primary inguinal hernia. Br J Surg., 2006; 93(9): 1056-1059.

25. Goldenberg A, Matone J, Marcondes W, Herbella FA, Farah JF, Comparative study of inflammatory response and adhesions formation after fixation of different meshes for inguinal hernia repair in rabbits. Acta Cir Bras., 2005; 20(5): 347-352.

26. Symeonidis D, Efthimiou M, Koukoulis G, Mamaloudis I, Ioannou M, Tzovaras G, Open inguinal hernia repair with the use of polyglycolic acid/trimethylene carbonate mesh: gross and pathologic assessment of the inguinal area at reoperation for recurrence. Hernia, 2013; 17(6): 791-794. 